JPE (Jurnal Pendidikan Edutama) Vol. 6 No. 2 Juli 2019

P-ISSN : 2339-2258 (Print) E-ISSN: 2548-821X (Online)

http://ejurnal.ikippgribojonegoro.ac.id/index.php/JPE

\title{
IMPROVING READING COMPREHENSION OF THE SECOND GRADE STUDENTS BY USING GRAPHIC ORGANIZER
}

\author{
Ahmad Syukron Sidik \\ Fakultas Keguruan dan Ilmu Pendidikan, Universitas Qamarul Huda \\ email: Syukron47@gmail.com
}

\begin{abstract}
The preliminary research of this research showed that the students had problems with reading comprehension known from their score. The students got 55 as their reading comprehension score where as the score of the student's report card was 68. Therefore, this present study employed Classroom Action Research (CAR) which involves four stages of research. They were (1) Planning, (2) Implementing, (3) Observing, and (4) Reflecting. The instruments used to collect data in this research are field note, observation checklist, and reading comprehension test. This research was done in one cycle which consists of three meeting and it set score 63 in average as the criterion of success based on the researcher and the English teacher discussion. This criterion of success considered the students' reading comprehension ability and the classroom circumstance. The result of this study above draws us into the conclusion that the graphic organizer Method improves the student's reading comprehension. This proved by the increasing of their score and behavior during the implementation of the method. Thus, graphic organizer method is an effective method in improving student's reading comprehension.
\end{abstract}

Keywords: Reading comprehension, graphic organizer method, classroom action research

\begin{abstract}
Abstrak
Studi pendahuluan dari penelitian ini menunjukkan bahwa siswa memiliki masalah dengan kemampuan membaca yang diketahui dari skor mereka. Para siswa mendapat 55 sebagai skor pemahaman bacaan mereka sedangkan skor kartu laporan siswa adalah 68. Oleh karena itu, penelitian ini menggunakan Penelitian Tindakan Kelas (PTK) yang melibatkan empat tahap penelitian. Mereka adalah (1) Perencanaan, (2) Implementing, (3) Observing, dan (4) Reflecting. Instrumen yang digunakan untuk mengumpulkan data dalam penelitian ini adalah catatan lapangan, daftar observasi, dan tes membaca pemahaman. Penelitian ini dilakukan dalam satu siklus yang terdiri dari tiga pertemuan dan menetapkan skor rata-rata 63 sebagai kriteria keberhasilan berdasarkan pada peneliti dan diskusi guru bahasa Inggris. Kriteria keberhasilan ini mempertimbangkan kemampuan pemahaman membaca siswa dan keadaan kelas. Hasil penelitian ini di atas menarik kita ke kesimpulan bahwa Metode grafik organizer meningkatkan pemahaman membaca siswa. Ini dibuktikan dengan meningkatnya skor dan perilaku mereka selama implementasi metode. Dengan demikian, metode grafik organizer adalah metode yang efektif dalam meningkatkan pemahaman membaca siswa.
\end{abstract}

Kata kunci: Pemahaman membaca, metode grafik organizer, penelitian tindakan kelas

\section{INTRODUCTION}

English is an international language used most people in the world. It connects people from different countries, races, and languages. There are four main skills in learning English i.e. speaking skill, writing skill, listening skill, and reading skill. Reading skill deals with students' 
interactive process between areader and a text which leads to automaticity or reading fluency (Alyousef, 2005). Reading skill is a complex activity which involves cognitive process. The purpose of equipping students with particular reading comprehension is to train them toget general and specific information from the text. Reading is the most important since every aspect of life involves reading, for example, road signs, traffic regulation, menus in restaurant, labels on cans, printed advertisements, newspaper, magazines insurance forms and so forth (Burn, 1996).

The problems found by the researcher on the teaching reading process in the classroom, especially for the second grade students of SMK Qamarul Huda Badaruddin are unable to comprehend the reading text given by teacher, because they cannot find the content of the text. Gabb (2000) states that a number of barriers for the reader is limited vocabulary ang lack of background knowledge (schematic knowledge). Reading strategy can enhance students' ablity to read and learn more effectively (Whorter \& Kathleen, 1983). The problem makes the students are less motivated on the learning and teaching process. The problems presented above are proved by the expected score of the secondgrade students of SMK Qamarul Huda Badaruddin is below the standard i.e. 55 in average. While the students' expected score in their report card was 68 in average. It indicates that the reading performance of second semester students is poor. Therefore, the researcher would like to increase the score by using graphic organizer method. The key point of understanding a text is to find the core point the ideas of the text.

As they become more aware of studying texts, students look for structure how the important imformationand ideas are organizedin text-in everything they read (Vacca \& Vacca, 1999). Graphic organizers are valuable tools for teaching/instruction. Unlike others, graphic organizers demonstrate a flexibility and endlessness in choices of use. Grabe (2009) One consequency of the emphasis of L1 reading comprehension research is that this part is primarily priented to reading ability more general rather than to a specific explanation of second language L2 reading comprehension. A common trait is their ability to show the order and completeness of the students' thought process how their understands becomes clearly evident. Using a range of graphic organizers shows both the close-up and the larger picture. Since many graphic organizers use short words or phrases, they are ideal for many types of learners (http://www.graphic.org).

Graphic organizers, according to Hall (2008), are visual representations or visual displays that show the connections of facts in pictures. In almost the same way, Judith B.S. (2006) states "A graphic organizer is a visual and graphic representation of relationships among ideas and concepts". In other words, "graphic organizers are two-dimensional visual arrays showing relationships among concepts" (Rice, 1994), or "graphic organizers are visual representation of knowledge that structures information by arranging important aspects of a concept or topic into a pattern using labels" (Bromley, DeVitis \& Modlo, 1999).

The researcher chooses teaching English reading using graphic organizer method because of two reasons. First, by using graphic organizer, researcher believes that the students will be easy to understand a certain English text. Second, they are motivated to read more and more because they can understand what the writer would like to deliver through the text. It makes the students are able to comprehend the text easily, which finally can improve their reading comprehension. Graphic organizers help students construct meaning. The following learning tools can be used with any book and across all grade levels. Use them to assess your students understanding of what they are reading, observe their thinking process on what you read as a 
class, as a group, or independently. However, the implementation of graphic organize method is one of the effective strategy to teach reading comprehension.

The issues the writer is, at present concerned with seem to be related to some previous studies. Syaifudin (2010) conducted a study at SMA Negeri 6 Surakarta with revealed that students could improve their critical reading ability in classroom learning. Setyo (2013) conduct a research to improve students reading comprehension at SMPN 15 Yogyakarta. From the findings described above, it can conclude that the teaching of reading by using organize method may improve students' reading ability.

The researcher expects the result of this study may give a positive contribution in teaching English for reading comprehension with graphic organizer method. It is expected giving a worthwhile contribution to the development of teaching quality in the classroom in order to improve the students' reading comprehension and support the teacher in constructing suitable material based on the students' need, knowledge, and interest.

\section{METHOD}

This research is aimed to improve reading comprehension by using graphic organizer method of the second-grade students at SMK Qamarul Huda Badaruddin Lombok. The research design employed for this research is CAR (Classroom Action Research). The product of classroom action research is an innovative instructional strategy that has proved useful in solving the classroom problems (Latief, 2012:188). CAR is a reflective process which helps a teacher to explore and examine aspects of teaching and learning and to take action to change and improve his teaching practice.
In this research the researcher involves in the action teaching and learning process, collecting and analyzing data, also making a conclusion and report. The result of this research is the description of the process in teaching reading to the students by using graphic organizer method. Since the study belongs to Classroom Action Research, it is done in a cycle process. The steps in each cycle are (1) planning of action (2) implementing and observing the process and consequences of the change (3) reflecting on these and consequences and then replanning (4) acting and observing, reflecting and so on, as proposed by kemmis \& Taggart (1988).

The process was stopped when the researcher found that students reach the criteria of success and the problem was considered to be solved. Observation checklist was used by the teacher to obtain the information concerning the result of the students' writing performance to know whether their performance achieved the goal of the study. A field note is one of instruments used to record any information during teaching and learning activity. The researcher will take note regularly while teaching the students.

This instrument is purposed to know the progress of the students and record activities in teaching and learning process. There were three kinds of data gathered in this study. The first data were those concerning with the result of students' achievement involved during the teaching and learning process, the second data were concerning with the result of students' motivation to speak during the teaching and learning process, and the third performance grades namely in their confidence, vocabulary performance, grammatical accuracy, pronunciation, and fluency.

The researcher then classified the data into two types: quantitative and qualitative data. The qualitative data were 
obtained from observation checklist and field notes. The quantitative data were obtained from the students' speaking performance grades in the criteria of vocabulary performance, grammatical accuracy, pronunciation, and fluency in the analytic scoring rubrics. The students were considered to be successful if the mean of score is 7.5 , the students had fulfilled the criteria of success.

\section{RESULT AND DISCUSSION}

The researcher has collected the data during the research using three different instruments: field note, observation check list, and reading comprehension test. The result of this cycle proved that students involve actively in the teaching and learning process of speaking. To obtain the data, the researcher some instruments such as: observation checklist, and the field note. The data were taken during the activity in the classroom. The observation checklist and field note indicate that students were actively involved in the classroom. The researcher concluded that the students were more active, enthusiastic, and enjoyed doing all the activities. The result of the test showed that the students' reading comprehension score was 75 in average.

Thus, the students' reading comprehension was improved from 55 in average in the preliminary study to 75 after the researcher implemented the method in the classroom with the lowest score was 63.3 and the highest one was 80 , from the test result, the researcher found that $100 \%$ had score above the criteria of success. The researcher also assumes by using graphic organizer method can improves students' activeness, enthusiasm, and also their low proficiency of reading comprehension. The data obtained from observation checklist and the field note analyzes also support the researcher statement. Although the researcher only used one display of the graphic organizer method, the researcher can conclude that this method could improve students' reading comprehension. Thus, the result of the cycle had been fulfilled the criteria of success of this study.

The result of the research was discussed on the basis of the relevant theories under the study of the use graphic organizer method to improve reading comprehension of the second-grade students of SMK Qamarul Huda Badaruddin Lombok Tengah. It was proven by the research findings that teaching reading comprehension using graphic organizer method improved students' reading comprehension. The students' score improved from 63 in the field note also showed that the students' quality of learning activity in the classroom was improved the students' enthusiasm, activeness and enjoyment during the teaching and learning process in reading comprehension using graphic organizer method had undergone a change from the first meeting to the last meeting.

Activate their prior knowledge of the text is the first step of this method. Then, the students are asked to read the text while pointing out the key word or any important words and difficult words from the sentences they read. Next, the students are asked to draw a graphic which is connected with the content of the text. They should write down they key or important words in the graphic. The graphic they choose will lead them to the text comprehension supported by the discussion they make with other friends. At the end of the method, the students should conclude and retell the text based on the graphic they draw briefly. The results of this study are in line with rice's statement (2010) graphic organizer method is a useful method in helping the students to visualize the structural element of a text to comprehend the content of the text. Strongman (2003) also states that graphic 
organizer has an ability to improve students' reading comprehension.

He collected some evidences that of 12 studies 9 studies reported graphic organizer method could elevate the students' reading comprehension. Similar to the statements above, Latendre (2000) reports that the students can comprehend the concept behind what they are reading and isolate not important text so that they can understand what they read. Jiang and Grabe (2007) also recommended the use of graphic organizer in comprehension instruction forthere were many evidences of research that support the elevation of reading comprehension and graphic organizer method. Thus, the researcher can draw a conclusion from the statements above that the use graphic method can improve students' reading comprehension of the second grade of SMK Qamarul Huda Badaruddin in the teaching and learning process

\section{CONCLUSION}

Based on the findings of this research, the researcher concluded that graphic Organizer method could improve the students' reading comprehension of text,

Particularly in Spoof text. Graphic organizer method can organize the students' thought concerning the text they read. Moreover, graphic organizer method can find the connection between one sentence to other sentences in which it is represented by the display of the words or phrases the students make, so that they can comprehend the content of the text. The activities of graphic organizer method can improve students' vocabulary through finding the important words, key words, or the difficult word they found in the text. The test result showed that the ability of students' reading comprehension was improved. The score of the students in the preliminary study was 55 in average while the score after implementing the method was 72.7 in average. This proves that graphic organizer method can improve students' reading comprehension achievement. In the graphic organizer method, the students are trained to get accustomed in comprehending a text. At the first stage, they should deal with the information of the text that they have had before. It will lead them into other information of the text. Then, instead of reading unimportant words, the students should find the important ones in order they grasp only the main point of every sentence or paragraph. Then, after making a display of vertical rectangles, the students should put the important words in the box in which every rectangle connects with the other ones with arrows. The display is very helpful for the students to understand the connection of the important point in a sentence to another one in the text. Finally, the display they drew will also lead them to a good comprehension of the whole text. When they face doubt in comprehending the text, the discussion with their friends in the end of the method will assure them with the answer. Moreover, this method can enrich students' vocabulary and improve the teaching and learning process quality through the activities, and this method can organize students' though of the text, visualize their idea and though in form of graphic display and find connection between one display to other display. 


\section{REFERENCES}

Alyousef, H. S. (2005). Teaching Reading Comprehension to ESL/EFL Learners. The Reading Matrix, Vol. 5, No. 2.

Bromley, K., Irwin-DeVitis, \& Modlo, M., (1999). Graphic Organizers. New York: Scholastic Professional Books.

Burns, P. C., Belly, J. P., \& Elmor, P. R. (1996) Teaching reading in today's elementary school. Boston: Haughton Miffing Company.

Grabe, W. (2009). Reading in second language moving from theory to practice. Cambridge University Press

Hall, T., \& Strangman, N. (2008). Graphic organizers: A report or the National Center on Assessing the General Curriculum at the Center for Applied Special Technology. Portland, ME: Walch Education. http://www.graphic.org,

Jiang, X., \& Grabe W. (2007). Graphic organize in reading instruction research finding and issues. Reading in foreign language.

Judith B. S. (2006). Vocabulary building: Graphic Organizers and Mini-lessons. Scholastic.

Latief, M. A. (2012). Classroom Action Research in Language. StateUniversity of Malang: Malang.

Whorter, Mc. \& Kathleen T. (1983). College reading and study skills. $2^{\text {nd }}-$ Ed. Canada: little brown and Company.

Rice, G. E. (1994). Need for explanations in graphic organizer research. Reading Psychology: An International Quarterly. 15, 39-67. 